Research article

\title{
Morphological characters of Chaetoceros lorenzianus (Bacillariophyceae) isolated from North Arabian Sea after Tasman Spirit oil spill
}

\author{
Asma Tabassum ${ }^{1}$, Hina Baig ${ }^{2}$ and Aliya Rehman ${ }^{1}$ \\ ${ }^{1}$ Department of Botany, University of Karachi, Karachi, Pakistan \\ ${ }^{2}$ National Institute of Oceanography, Karachi, Pakistan
}

*Corresponding Author: centricdiatomist@gmail.com

[Accepted: 26 October 2016]

\begin{abstract}
The present study investigated the morphology and taxonomy of marine centric diatom Chaetoceros lorenzianus from Karachi Harbor, Pakistan for the first time for the first time during the incident of Tasman Spirit Oil Spill (2003) in the area. Phytoplankton samples were collected from 5 different locations from the study area. Chaetoceros lorenzianus was found only at one station collected after Tasman Spirit Oil Spill. Moreover morphometric measurements of present record showed narrow range as compared to the records investigated by other workers.
\end{abstract}

Keywords: Chaetoceros lorenzianus - Diatom - Phytoplankton - Tasman Spirit oil spill.

[Cite as: Tabassum A, Baig H \& Rehman A (2016) Morphological characters of Chaetoceros lorenzianus (Bacillariophyceae) isolated from North Arabian Sea after Tasman Spirit oil spill. Tropical Plant Research 3(3): 558-563]

\section{INTRODUCTION}

Phytoplankton are the major primary producers of marine and fresh water environment (Baliarsingh et al. 2012). Among phytoplankton, the Bacillariophyta (diatoms) contributes at least $40 \%$ of the global annual primary productivity (Field et al. 1998). These diatoms are ubiquitous occurrence in marine environment (Sunesen et al. 2008). Genus Chaetoceros Ehrenberg is considered as most diverse and wide spread centric diatom (Cupp 1943, Rines 1999, Hasle \& Syvertsen 1997). It comprises of about 400 marine species with few fresh water records (Round et al. 1990). Morphological and taxonomical studies of this genus contributed new records time to time from various parts of the world oceans (Hernandez-Becerril 1993, Hernandez-Becerril 1999, Rines 1999, Trigueros et al. 2002, Murthy et al. 2012, Ozgur et al. 2013). A number of studies have been conducted on distribution and composition of Chaetoceros (Hargraves 1972, Fanuko \& Valic, 2009, Tabassum \& Saifullah 2010). It was observed to be one of the most frequently occurring genus among centric diatoms (Nwankwo \& Onyema 2003, Tabassum \& Saifullah 2010). Records of Chaetoceros have also been well observed in sediments with special reference to their resting spores (Stockwell 1991, Witak et al. 2011, Ferrario et al. 1998, Moazzam \& Baig 1994). Variation in physiological behavior and their responses to hydrological parameters have also been studied (Johansen et al. 1990).

Chaetoceros lorenzianus, is considered to be a harmful bloom forming species (Sunesen et al. 2008). This species was studied by a number of scientists (Cupp 1943, Subrahmanyan 1946, Hendey 1964, Moazzam 1973, Hasle \& Syvertsen 1997, Shevchenko et al. 2006, Sunesen et al. 2008, Tabassum \& Saifullah 2010). Moreover the lysis of this species by a single stranded DNA virus has also been investigated (Tomaru et al. 2011). The occurrence of Chaetoceros lorenzianus has been discussed from various parts of the world ocean (Cupp 1943, Sunesen et al. 2008, Shevchenko et al. 2006, Wood 1963, Subrahmanyan 1946, Rajasekar et al. 2010, Hendey 1964) It is known from North Arabian Sea bordering Pakistan (Moazzam 1973, Saifullah \& Chaghtai 2005, Tabassum \& Saifullah 2010). This is the first attempt to study the impact of oil spill in North Arabian Sea on morphological characters of this species. 


\section{MATERIALS AND METHODS}

Phytoplankton samples were collected by net $(50 \mu \mathrm{m})$ hauls of 5 minute duration at speed of $2 \mathrm{~km}$ at 5 sampling stations which were selected in the area affected by oil spill (Fig. 1 and Table 1). Samples were fixed with $10 \%$ buffered formalin immediately after collection. Observations on oceanographic parameters like temperature, salinity and $\mathrm{pH}$ were also measured at each station.

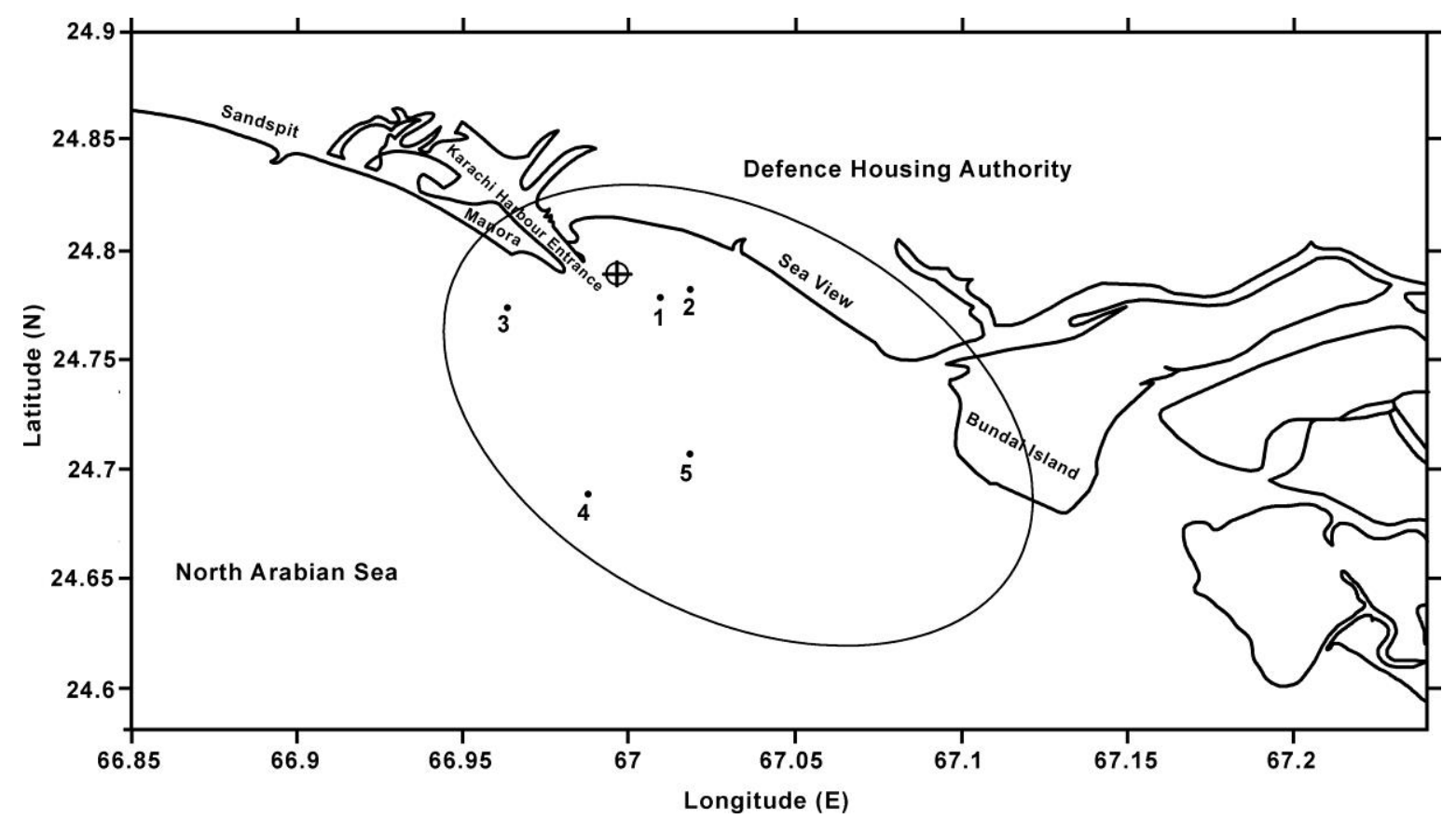

Figure 1. Map showing sampling stations of Tasman Spirit Oil Spill effected area.

Table 1. Sampling stations in off Karachi Harbour.

\begin{tabular}{llll}
\hline Station No. & Sampling date & Latitude N & Longitude E \\
\hline 1 & $19-11-03$ & $24^{\circ} 80^{\prime} 248 \mathrm{~N}$ & $66^{\circ} 89^{\prime} 938 \mathrm{E}$ \\
2 & $19-11-03$ & $24^{\circ} 80^{\prime} 816 \mathrm{~N}$ & $66^{\circ} 99^{\prime} 215 \mathrm{E}$ \\
3 & $19-11-03$ & $24^{\circ} 80^{\prime} 771 \mathrm{~N}$ & $67^{\circ} 01^{\prime} 087 \mathrm{E}$ \\
4 & $19-11-03$ & $24^{\circ} 79^{\prime} 753 \mathrm{~N}$ & $67^{\circ} 02^{\prime} 718 \mathrm{E}$ \\
5 & $20-11-03$ & $24^{\circ} 77^{\prime} 204 \mathrm{~N}$ & $67^{\circ} 05^{\prime} 435 \mathrm{E}$ \\
\hline
\end{tabular}

Samples were observed in light microscope LABX N-400M. Prior to scanning electron microscopy (SEM) the samples were cleaned by cold $\mathrm{H}_{2} \mathrm{O}_{2}$ method (Karthick et al. 2010). Cleaned material were coated up to 300 A with auto coater using JEOL \# JFC 1500 having gold targets. The coated samples were then scanned with JEOL \# JSM 6380A microscope. Present paper manifests the light and electron microscopic structures probably for the very first time in this study area.

\section{RESULTS}

Enumeration of species

Chaetoceros lorenzianus Grunow, 1863, 157, pl. 5: fig. 13; Cupp 1943, p. 118, Fig. 71; Subrahmanyan 1946, p. 131, Figs. 198-199, 202-204, 206-209 (p. 132); Hendey 1964, p. 124, Plate 16, Fig. 1; Hasle \& Syvertsen 1997, p. 204, Plate 42; Shevchenko et al. 2006, p. 249, Figs. 84-89; Sunesen et al. 2008, p. 317 \& 318, Fig. 11A-F; Tabassum \& Saifullah 2010, p. 1144 \& 1146, Fig. 13 (1145). (Fig. 2)

Chains straight, cells rectangular, apical axis 11-15 $\mu \mathrm{m}$. Apertures wide, elliptical to lanceolate, foramina hexagonal, ranges from 10-12 $\mu \mathrm{m}$. Setae thick, long, spiny, polygonal in cross section, fuse just near the margin, divergent with slight curve forming an angle of $35^{\circ}-45^{\circ}$ to the chain axis.

Distribution: During the present study this species was collected only from Station 2.

This species is reported by various parts of the world ocean. West Coast of North America (Cupp 1943); Madras, India (Subrahmanyan 1946); Chaleurs Bay Canada (Brunel 1962); Indian Ocean (Wood 1963); British Coastal Waters (Hendey 1964); Manora Channel Karachi (Moazzam 1973); Indian Ocean (Simonsen 1974); Peter the Great Bay, Sea of Japan (Shevchenko et al. 2006); Buenos Aires Argentina (Sunesen et al. 2008). www.tropicalplantresearch.com 
Observation from the study area: The valve profile of Chaetoceros lorenzianus is nearly close to the findings of numerous workers (Cupp 1943, Subrahmanyan 1946, Hendey 1964, Moazzam 1973, Hasle \& Syvertsen 1997, Shevchenko et al. 2006, Sunesen et al. 2008, Tabassum \& Saifullah, 2010) except the size of apical axis which is within a narrow range (Table 2). This may be attributed to their presence in the environment which was polluted with the crude oil because of Tasman Spirit oil spill which might have affected the cell metabolism. Parab et al. (2008) observed morphological changes in another centric diatom Thalassiosira because of oil exposure.
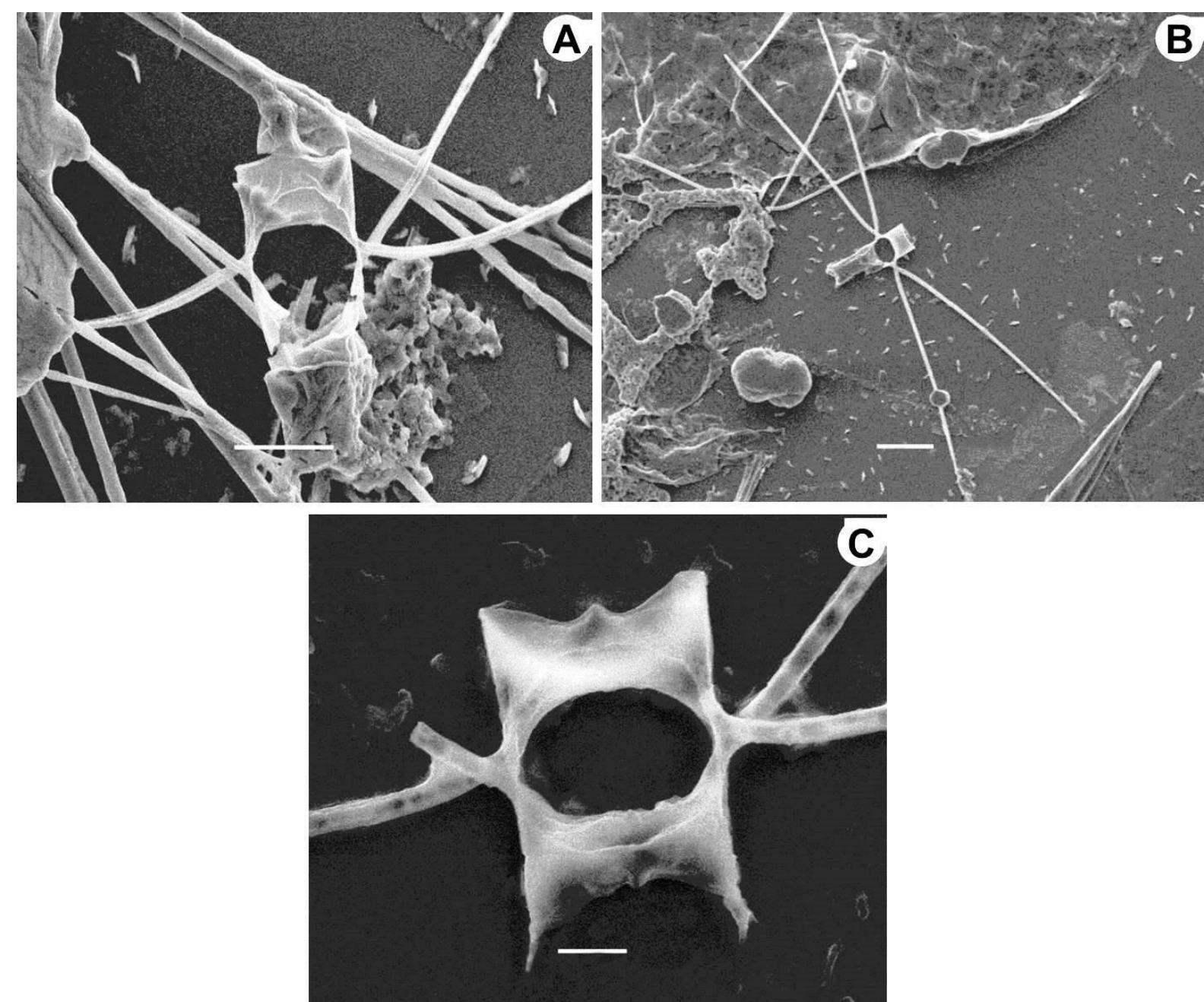

Figure 2. Chaetoceros lorenzianus (SEM, pair of sibling cells in girdle view): A, Scale bar: $10 \mu \mathrm{m}$; B, Sibling cells with long setae. Scale bar: $20 \mu \mathrm{m}$; $\mathbf{C}$, Sibling valves with wide aperture. Scale bar: $5 \mu \mathrm{m}$.

Table 2. Comparison of morphometric data among Chaetoceros lorenzianus of present study with the previous records.

\begin{tabular}{|c|c|c|c|c|c|c|c|c|}
\hline & $\begin{array}{l}\text { Cupp, } \\
1943 \\
\text { (Pacific } \\
\text { Ocean) }\end{array}$ & $\begin{array}{l}\text { Subrahman } \\
\text { yan, } 1946 \\
\text { (Indian } \\
\text { Ocean) }\end{array}$ & $\begin{array}{l}\text { Hendey, } \\
1964 \\
\text { (Atlantic } \\
\text { Ocean) }\end{array}$ & $\begin{array}{l}\text { Moazzam } \\
, 1973 \\
\text { (North } \\
\text { Arabian } \\
\text { Sea) } \\
\end{array}$ & $\begin{array}{l}\text { Hasle and } \\
\text { Syvertsen } \\
, 1997\end{array}$ & $\begin{array}{l}\text { Sunesen } \\
\text { et al., } \\
2008 \\
\text { (Atlantic } \\
\text { Ocean) } \\
\end{array}$ & $\begin{array}{l}\text { Tabassum and } \\
\text { Saifullah, } \\
2010 \\
\text { (North } \\
\text { Arabian Sea) }\end{array}$ & $\begin{array}{l}\text { Present } \\
\text { study } \\
\text { (North } \\
\text { Arabian } \\
\text { Sea) } \\
\end{array}$ \\
\hline Apical axis & $\begin{array}{l}7 \mu \mathrm{m}- \\
48 \mu \mathrm{m}\end{array}$ & $\begin{array}{l}16 \mu \mathrm{m}- \\
58 \mu \mathrm{m}\end{array}$ & $\begin{array}{l}26 \mu \mathrm{m}- \\
60 \mu \mathrm{m}\end{array}$ & $\begin{array}{l}5 \mu \mathrm{m}- \\
40 \mu \mathrm{m}\end{array}$ & $\begin{array}{l}7 \mu \mathrm{m}- \\
80 \mu \mathrm{m}\end{array}$ & $\begin{array}{l}16 \mu \mathrm{m}- \\
36 \mu \mathrm{m}\end{array}$ & $\begin{array}{l}15 \mu \mathrm{m}- \\
35 \mu \mathrm{m}\end{array}$ & $\begin{array}{l}10 \mu \mathrm{m}- \\
15 \mu \mathrm{m}\end{array}$ \\
\hline $\begin{array}{l}\text { Pervalvar } \\
\text { axis }\end{array}$ & - & - & - & - & - & - & $\begin{array}{l}10 \mu \mathrm{m}- \\
20 \mu \mathrm{m}\end{array}$ & $\begin{array}{l}7 \mu \mathrm{m}- \\
11 \mu \mathrm{m}\end{array}$ \\
\hline
\end{tabular}

\section{DISCUSSION}

Any change in the ecosystem of an aquatic environment can be determined by analysis of phytoplankton composition of that area (Guilloux et al. 2013). An extensive amount of studies have been conducted on effects of oil pollution on ecosystem of water bodies which showed deleterious effects on growth of phytoplankton community structure (Parab et al. 2008, Jiang et al. 2010).

www.tropicalplantresearch.com 
Genus Chaetoceros is termed as fast growing diatom and its domination among other members of phytoplankton was also observed during the studies conducted in the other parts of the world during stress condition of oil spill (Hallare et al. 2011). Chaetoceros lorenzianus collected from North Arabian Sea bordering Pakistan belongs to sub-genus Hyalochaete (Hasle \& Syvertsen 1997). In the present study morphometric data including apical axis and pervalver axis of Ch. lorenzianus was found in narrow range but at the same time within the range of the results recorded earlier by other workers (Table 2). It is recorded that the traces of oil (raw or refine) are lethal to autotrophic life forms as they can cease metabolic activities by limiting their enzymatic activities (Lewis \& Pryor 2013) and decrease chlorophyll 'a' concentration (Lee et al. 2009). As it is evident that the toxicity of crude oil is concentration dependent (Sheekh et al. 2000) and the species were recorded during the initial days of spill so recorded narrow range of morphometric measurements of the cells may accounted due to the effect of crude oil.

Moreover previous findings showed that Kuzmenko (1975), Tabassum \& Saifullah (2010) observed 16 species of Chaetoceros in the month of February from Arabian Sea whereas seven species of this genus including $C$. lorenzianus were reported in the month of October from Kuwait Bay, Arabian Sea (Heil et al. 2001). Present study manifests sporadic occurrence of the species in the month of November immediate after Tasman Spirit Oil Spill which may have attributed to the effect of oil spill in this area.

\section{ACKNOWLEDGEMENTS}

Authors are deeply indebted to National Institute of Oceanography, Pakistan for providing the samples of project entitled "Tasman Spirit Oil Spill" for this study. And we are also thankful to Dr. Ines Sunesen from Departamento Cientifico Ficologia, Universidad Nacional de La Plata, Argentina for constant support in this study.

\section{REFERENCES}

Baliarsingh, SK, Biraja KU, Srichanda S \& Sahu KC (2012) Seasonal variation of phytoplankton community in Navigable Channel of Gopalpur Port, East coast of India: A Taxonomic study. International Journal of Modern Botany 2(3): 40-46.

Cupp EE (1943) Marine plankton diatoms of the West Coast of North America, Bulletins of the Scripps Institution of Oceanography 5: 1-238.

Fanuko N \& Valic M, 2009 Phytoplankton composition and biomass of the northern Adriatic lagoonof Stella Maris, Croatia Acta Botanica Croatica 68(1): 29-44.

Ferrario ME, Sar EA, \& Vernet M (1998) Chaetoceros resting spores in the Gerlache Strait, Antarctic Peninsula. Polar Biology 19: 286-288.

Field CB, Behrenfeld MJ, Randerson JT \& Falkowski P (1998) Primary production of the biosphere: integrating terrestrial and oceanic components. Science 281(5374): 237-240.

Guilloux L, Riguat-Jalbert F, Jouenne F, Ristori S, Viprey M, Not F, Vaulot S \& Simon N (2013) An annotated checklist of Marine Phytoplankton taxa at the SOMLIT-Astan time series off Roscoff (Western English Channel, France): data collected from 2000 to 2010. Cahiers De Biologie Marine 54: 247-256.

Hallare AV, Lasafin KJA, \& Magallanes JR (2011) Shift in Phytoplankton community structure in a tropical marine reserve before and after a major oil spill event. International Journal of Environmental Research 5(3): 651-660.

Hargraves PE (1972) Studies on marine plankton diatom.1. Chaetoceros diadema (Her.) Gram: life cycle, structural morphology and regional distribution. Phycologia 11(3\&4): 247-257.

Hasle GR, Syvertsens EE (1997) Marine Diatoms. In: Tomas CR (ed) Identifying Marine Phytoplankton. Academic Press, San Diego, California, pp. 1-385.

Heil CA, Patricia M, Glibert MA, Al-Sarawi MF, Manaf B \& Muna H (2001) First record of a fish killing Gymnodinium sp. bloom in Kuwait Bay, Arabian Sea: Chronology and potential causes. Marine Ecology Progress Series 214: 15-23.

Hendey NI (1964) An introductory account of the smaller algae of British coastal waters. Part 5: Bacillariophyceae (Diatoms). Her Majesty's Stationery Office, London.

Hernandez-becerril DU (1999) Chaetoceros sumatranus, a member of Chaetoceros section Coarctati, sect. nov. (Bacillariophyceae). Cryptogamie Algologie 20(2): 95-104. 
Jiang Z, Huang Y, Xu X, Liao Y, Shou L, Liu, J, Chen Q \& Zeng J (2010) Advance in the toxic effects of petroleum water accommodated fraction on marine plankton. Acta Ecologia Sinica 30(1): 8-15.

Johansen JR, Barclay WR \& Nagle N (1990) Chaetoceros muelleri (Bacillariophyceae): Physiological variability within ten strains. Journal of Phycology 26: 271-278.

Karthick B, Jonathan CT, Mahesh MK \& Ramachandra TV (2010) Protocols for collections, preservation and enumeration of diatoms from aquatic habitats for water quality monitoring in India. The IUP Journal of Soil \& Water Sciences III(1): 25-60.

Kuzmenko V (1975) Systematic composition of phytoplankton of Arabian Sea. Biology of the Sea, 34: 15-261.

Lee CII, Kim MC \& Kim HC (2009) Temporal variation of chlorophyll a concentration in the coastal waters affected by the Hebei Spirit oil spill in the west sea of Korea. Marine Pollution Bulletin 58: 496-502.

Lewis M \& Pryor R (2013) Toxicities of oils, dispersants and dispersed oils to algae and aquatic plants: Review and database value to resource sustainability. Environmental Pollution 180: 345-367.

Martha EF, Eugenia AS \& Maria V (1998) Chaetoceros resting spores in the Gerlache Strait, Antarctic Peninsula. Polar Biology 19: 286-288.

Moazzam M \& Baig HS (1994) Species composition of phytoplankton in Antarctic waters observed during Pakistan's Antarctic Expedition. Marine Research 3(2): 1-43.

Moazzam M (1973) Taxonomic and seasonal studies of planktonic centric diatoms from Manora channel (Lower Harbour) Karachi, M.Sc. Thesis. Department of Marine Biology. University of Karachi.

Murthy KN, Babu MN, Annapurna C \& Sarma NS (2012) First record of Chaetoceros minims (Bacillariophyceae) from the Indian waters. Marine Biodiversity Records 5: 1-4.

Nwanko DI \& Onyema IC (2003) A check list of planktonic algae off lagos coast. Journal of Marine Science Research \& Development 9: 75-82.

Ozgur B, Ojvind M, Nina L \& Arif G (2013) Contributions to the Diatom flora of the Black Sea from ultrastructural and molecular studies: new records of Skeletonema marinoi, Pseudo-nitzschia pugens var. aveirensis and Chaetoceros tenuissimus for the marine flora of Turkey. Nova Hedwigia Band 96(3-4): 427444.

Parab SR, Pandit RA, Kadam AN \& Indap MM (2008) Effect of Bombay high crude oil and its water-soluble fraction on growth and metabolism of diatom Thalassiosira sp. Indian Journal of Marine Sciences 37(3): 251-255.

Rajasekar T, Rajkumar M, SUN J, Ashok PV \& Perumal P (2010) Seasonal variation of phytoplankton diversity in the Coleroon coastal waters, southeast coast of India. Acta Oceanologica Sinica 29.

Rines JEB (1999) Morphology and taxonomy of Chaetoceros contortus Schutt 1895, with preliminary observations on Chaetoceros compressus Lauder 1864 (Subgenus Hyalochaete, Section Compressa). Botanica Marina 42: 539-551.

Round FE, Crawford RM \& Mann DG (1990) The Diatoms, Biology \& Morphology of the Genera. Cambridge University Press, Cambridge, pp. 1-747.

Saifullah SM \& Chaghtai F (2005) Effect of "Tasman Spirit" oil spill on marine plants in the coastal area of Karachi. International Journal of Biology Biotechnology 2(2): 299-306.

Sheekh MM, Nagger AE, Osman MEH \& Haieder A (2000) Comparative studies on the green algae Chlorella homosphaera and Chlorella vulgaris with respect to oil pollution in the river Nile. Water, Air, \& Soil Pollution 121: 187-201.

Shevchenko OG, Orlava TY \& Hernandez-Becerril DU (2006) The Chaetoceros (Bacillariophyta) from Peter the Great Bay, Sea of Japan. Botanica Marina 49: 236-258.

Simonsen R (1974) The diatom plankton of the Indian Ocean Expedition of R/V “Meteor" 1964-1965. "Meteor" Forchungsergebnisse, 41pl. Gebruder Borntrager, Berlin, pp. 66.

Stockwells DA (1991) Distribution of Chaetoceros resting spores in the quaternary sediments from Leg 119. In: Barron J, Larsen B et al. (eds) Proceedings of Ocean Drill. Program, Scientific Results 119: 599-610.

Subrahmanyan R (1946) A systematic account of the marine plankton diatoms of the Madras coast. Proceedings of the Indian Academy of Science 24B: 85-197.

Sunesen I, Hernandez-Becerril DU \& Sar EA (2008) Marine diatoms from Buenos Aires coastal waters (Argentina). V. Species of the genus Chaetoceros. Revista de Biologia Marina Oceanografia 43(2): 303326. 
Tabassum A \& Saifullah SM (2010) The planktonic diatom of the genus Chaetoceros Ehrenberg from northwestern Arabian Sea bordering Pakistan. Pakistan Journal of Botany 42(2): 1137-1151.

Tomaru Y, Yoshitake T, Hidekazu S, Tamostsu N, Kanae K \& Keizo N (2011) Isolation and characterization of a single-stranded DNA virus infecting Chaetoceros lorenzianus Grunow. Applied and Environmental Microbiology 77(15): 5285-5293.

Trigueros JM, Orive E \& Arriluza J (2002) Observations on Ch. Salsugineus (Chaetocerotales, Bacillariophyceae): first record of this bloom-forming diatom in a European estuary. European Journal of Phycology 37: 571-578.

Witak M, Dunder J \& Leniewska M (2011) Chaetoceros resting spores as indicators of Holocene paleoenvironmental changes in the Gulf of Gdansk, Southern Baltic Sea. Oceanological and Hydrobiological Studies 40: 21-29.

Wood EJF (1963) Checklist of diatoms recorded from the Indian Ocean. Rep Div Fish Oceanogr CSIRO 36: 1304. 